\title{
Partial characterization of two novel monoclonal antibodies for Listeria spp. Immunodetection
}

\author{
Gustavo Moreira*, Marcelo Mendonça, Fabricio Conceição \\ From 5th Congress of the Brazilian Biotechnology Society (SBBIOTEC) \\ Florianópolis, Brazil. 10-14 November 2013
}

\begin{abstract}
Background
The Listeria genus comprises ten different species, however, only two of them - L. monocytogenes and L. ivanovii are pathogenic. Although being a well-known pathogen, its detection methodologies are still limited. The goldstandard technique involves enrichment, isolation, and biochemical characterization, which can take about 7 days [1]. In addition, since both pathogenic and non-pathogenic species are present in contaminated food, it is important to detect them both [2]. This way, new methods, such as the immunodetection using monoclonal antibodies (MAbs), have been developed to reduce the detection time of Listeria spp.. Recently, our group described a hybridoma clone secreting a MAb of the IgM isotype, called MAb$3 \mathrm{~F} 8$, that reacts exclusively with an antigen of $30 \mathrm{kDa}$ (P30) present in all Listeria spp. evaluated [3]. In the present work, we produced and initially characterized, by ELISA and Western blot, other two novel antibodies against P30 to be used in Listeria spp. immunodetection assays.
\end{abstract}

\section{Materials and methods}

A female BALB/c mouse was initially inoculated intraperitoneally with $100 \mu \mathrm{g}$ of recombinant P30 (rP30) with complete Freund's Adjuvant (FA). Fifteen days after the first injection, a series of 13 doses of rP30 with incomplete FA were performed weekly. Then, the mouse splenocytes were obtained and further fused with $\mathrm{Sp} 2 / \mathrm{O}$ cells. The resulting hybridomas were cultured and screened by ELISA using both rP30 and formalin-killed L. monocytogenes strain ATCC 19117 (Lm19117) as antigens. Thereby, two hybridomas were selected and used to produce ascites in mice [4]. MAbs isotyping kit (Sigma Aldrich) was used to determine the isotype of each MAb. For the ELISA, rP30 and formalin-killed Lm19117 and L. innocua (Linn) were used as antigens.

Centro de Desenvolvimento Tecnológico, Núcleo de Biotecnologia, Universidade Federal de Pelotas, Pelotas, Rio Grande do Sul, 96010-900, Brazil
For the Western blot (WB), Lm19117 cell-wall fraction [5] and rP30 were transferred to a PVDF membrane. In both assays, the ascites and anti-mouse/peroxidase (Sigma Aldrich) were primary and secondary antibodies, respectively. In addition, 3F8 (positive control) and a non-immunized mouse serum (negative control) were used. Absorbance results at least 3 times higher than the negatives were considered positives.

\section{Results and conclusions}

The isotyping assay determined that one MAb was IgG1 (MAb-G2A) and the other, IgM (MAb-M5A). In the ELISA, MAb-G2A reacted with $\mathrm{rP30}\left(\mathrm{OD}_{450}=0.346\right)$, but not with $\mathrm{Lm} 19117\left(\mathrm{OD}_{450}=0.020\right)$ or Linn $\left(\mathrm{OD}_{450}=0.018\right)$. However, M5A reacted with $\mathrm{rP30}\left(\mathrm{OD}_{450}=0.160\right)$, Lm19117 $\left(\mathrm{OD}_{450}=0.229\right)$, and Linn $\left(\mathrm{OD}_{450}=0.199\right)$. Negatives for rP30, Lm, and Linn were 0.026, 0.048, and 0.062 , respectively; while the positives were $0.418,0.237$, and 0.211 , respectively. In the $\mathrm{WB}$, the same pattern seem to occur with MAb-G2A, since it reacted only with rP30; while MAb-M5A presented no reaction. The fact that M5A had no reaction in WB, but showed promising results in ELISA indicate this MAb binds to a conformational epitope of P30 that is displayed on Listeria surface. Considering this, further studies will be conducted with a larger panel of bacteria to better characterize these MAbs and determine their sensibility and specificity in detecting Listeria spp. in food samples.

\section{Acknowledgements}

We would like to thanks CAPES, CNPq and FAPERGS for the financial support and scholarships.

\section{Published: 1 October 2014}

\section{References}

1. Gasanov U, Hughes D, Hansbro PM: Methods for the isolation and identification of Listeria spp. and Listeria monocytogenes: a review. FEMS microbiology reviews 2005, 29:851-75. 
2. Besse NG, Barre L, Buhariwalla C, Vignaud ML, Khamissi E, Decourseulles $E_{\text {, }}$ Nirsimloo M, Chelly M, Kalmokoff M: The overgrowth of Listeria monocytogenes by other Listeria spp. in food samples undergoing enrichment cultivation has a nutritional basis. International journal of food microbiology 2010, 136:345-351.

3. Mendonça M, Conrad NL, Conceição FR, Moreira AN, da Silva WP, Aleixo JAG, Bhunia AK: Highly specific fiber optic immunosensor coupled with immunomagnetic separation for detection of low levels of Listeria monocytogenes and L. ivanovii. BMC microbiology 2012, 12:275.

4. Misra SK, Milohanic E, Aké F, Mijakovic I, Deutscher J, Monnet V, Henry C: Analysis of the serine/threonine/tyrosine phosphoproteome of the pathogenic bacterium Listeria monocytogenes reveals phosphorylated proteins related to virulence. Proteomics 2011, 11:4155-4165.

5. Harlow E, Lane D: Antibodies: A Laboratory Manual. New York: Cold Spring Harbor; 1988.

doi:10.1186/1753-6561-8-S4-P64

Cite this article as: Moreira et al:: Partial characterization of two novel monoclonal antibodies for Listeria spp. Immunodetection. BMC

Proceedings 2014 8(Suppl 4):P64.

\section{Submit your next manuscript to BioMed Central} and take full advantage of:

- Convenient online submission

- Thorough peer review

- No space constraints or color figure charges

- Immediate publication on acceptance

- Inclusion in PubMed, CAS, Scopus and Google Scholar

- Research which is freely available for redistribution

Submit your manuscript at www.biomedcentral.com/submit 